\title{
Intellectual Property on the Cyber-Picket Line: A Comment on BRITISH Columbia AUTOMobILE ASSN. v. OfFICE AND PROfESSIONAL EMPLOYEes' INTERNATIONAL UNION, LOCAL 378
}

\author{
TERESA SCASSA
}

\section{INTRODUCTION}

A recent decision from the British Columbia Supreme Court, British Columbia Automobile Assn. v. O.P.E.I.U., Local 378, ' raises issues of "passing off," trademark, and copyright infringement relating to web sites, domain names, ${ }^{2}$ and meta tags. ${ }^{3}$ In this comment I will explore these issues, all of which may commonly arise in situations of alleged competition between web sites. The case thus provides a context for exploring legitimate and unlawful uses of domain names and meta tags, copyright infringement, and web site design, and it touches on the role of s. 22 of the Trade-marks Act. ${ }^{4}$ Because $B C A A$ also occurs in the context of a labour dispute, it raises further issues about intellectual property rights and freedom of expression. These issues have arisen before in the non-Internet labour dispute cases of Cie Générale des Établissements MichelinMichelin \& Cie v. C.A.W.-Canada ${ }^{5}$ and Rotisseries St-Hubert Ltée v. le Syndicat des Travailleurs(euses) de la Rotisserie St-Hubert De Drummondville (C.S.N.), ${ }^{6}$ and their resolution continues to raise serious concerns about the balance being struck between monopolistic intellectual property rights and the fundamental right of freedom of expression.

The plaintiff, British Columbia Automobile Association ("BCAA"), a member of the national Canadian Automobile Association ("CAA"), sued the defendant Office and Professional Employees' Union ("Union") over three successive web sites created by the Union to publicize a strike by BCAA employees. The BCAA's claims related to the close resemblance between the first two Union web sites and the plaintiff's own web site, the use of meta tags similar to those used in the BCAA site, and the use of domain names

- Associate Professor, Associate Dean, Dalhousie Law School. I would like to thank my research assistant Tina Piper for her invaluable assistance in preparing this paper. I would also like to thank Dianne Pothier and Charles Sanders for their helpful comments.

1 (2001), 10 C.P.R. (4th) 423 [hereinafter BCAA].

2 Domain names are words, names, or other text that are mapped to numerical Internet protocol addresses which provide the location of particular machines or servers. A domain name typically consists of the second level domain (often a company's trademark or business name) followed by a top level domain ("TLD"). This may be one of the generic TLDs, such as .com, net, or .org, or it may be a country code TLD such as .ca for Canada.

" Meta tags consist of hidden Hypertext Markup Language ("HTML") codes, which do not automatically appear when a user visits a web site. The meta tags typically contain key words or phrases that describe the web site and its contents. They are used by search engines to match particular web sites with the key words entered by a user of the search engine.

$4 \quad$ R.S.C. 1985 , c. T-13.

3 (1996), 71 C.P.R. (3d) 348 (F.C.T.D.) [hereinafter Michelin].

" (1986), 17 C.P.R. (3d) 461 (Qc. Sup. Ct.) [hereinafter Rotisseries St-Hubert]. 
that incorporated the plaintiff's logo, such as "bcaaonstrike.com" and "bcaabacktowork.com."

The BCAA first established a web presence in 1995. Its new web site, which was at the centre of the controversies in this case, was created in 1997. The site is located both at $<w w w$.bcaa.com $>$ and $<w w w$.bcaa.org $>$. BCAA is licensed to use the CAA trademarks and certification marks. BCAA, CAA, and the CAA logo are all registered trademarks in relation to goods and services. They are also registered certification marks for goods and services. The BCAA uses the CAA and BCAA trademarks, including the CAA logo on its site. The court found that BCAA had used these marks extensively since 1983.

The defendant Union, OPEIU, represented some of the BCAA employees at the Association's different offices throughout the province. In January of 1999 the employees represented by the Union initiated a lawful strike. Shortly after the onset of the strike, in March of 1999, the Union created a web site that was similar in appearance to the BCAA site. The Uniform Resource Locators ("URLs") for this web site were $<w w w$.bcaaonstrike .com $>$ and <www.picketline.com>. Following complaints by lawyers of the BCAA, the site was modified in April of 1999. In October of 1999 the Union adopted a significantly different web site. In February of 2000 a third URL was added which pointed to the Union site. That URL was <www.bcaabacktowork.com>. All three Union sites were at issue in the lawsuit under discussion. However, the allegations varied with respect to each of the sites; thus some description of the three sites is necessary.

The first site, created in March 1999 ("Site 1"), was alleged to infringe copyright in the design elements of the BCAA site. In particular, it was alleged that the following features of Site 1 were similar to those of the BCAA site:

[T]he shape, structure, colour scheme and layout of the Web site; the placement of the CAA Logo (although inverted in the Union Web site design); the appearance, placement and juxtaposition of the words "BCAA ON-RAMP" (although the Union Web site design replaced "ON" with "OFF"); and the format, layout and colour scheme of the materials that appeared within the frames of the Web site.?

In April 1999 the site was modified in a number of ways ("Site 2"). In particular, the CAA logo was removed, the BCAA acronym was changed from upper to lower case lettering, and the message "Greetings, BCAA is on strike" was moved so that most of the wording could not be seen on a standard screen. In October of 1999 the site was substantially redesigned. In this third version ("Site 3") no CAA or American Automobile Association ("AAA") trademarks were used; the reference to the "BCAA Off-ramp" was removed; "British Columbia, Automobile, Association" in the meta tags was substituted for "British Columbia Automobile Association"; "BCAA On Strike" was substituted for "BCAAonstrike." In addition, the message "Greetings, BCAA is on strike" was replaced with "Greetings, OPEIU is on strike against BCAA." In spite of the differences in

$B C A A$, supra note 1 at 435 .

Note that descriptions of the web sites are culled from the facts of the case, as the first two Union web sites were no longer operative at the time of writing. At the time of writing, however, the URL $<w w w$.picketline.com> provided access to the OPEIU web site. The meta tags for that site are as 
appearance between each of the three sites, all three sites used "a substantial part" of the BCAA web site meta tags. The three sites used the same URLs: <bcaaonstrike.com>, <picketline.com>, and <bcaabacktowork.com>.

The Court addressed three main arguments in the case. First, the BCAA alleged passing off against the Union sites because of its use of BCAA's domain names and meta tags. The second main argument was that in each of its web sites the Union had used the plaintiff's trademarks without permission, and in a manner so as to depreciate the value of the goodwill associated with the trademarks, in contravention of s. 22 of the Trademarks Act. The third argument was that Site 1 and Site 2 infringed the copyright the plaintiff held in its own web site. The passing off and trademark law issues will be considered first, followed by the questions of copyright infringement, fair dealing, and freedom of expression.

\section{Passing OFF}

The BCAA argued that all three versions of the Union's web site constituted passing off. While no passing off was found with respect to Sites 2 and 3, Sigurdson J. did find passing off in Site 1. While focusing almost exclusively on the element of confusion or misrepresentation, Sigurdson J. also found the particular context of a labour dispute to be relevant to his analysis. This section of the comment will assess Justice Sigurdson's analysis of confusion, giving particular weight to an evaluation of confusion as it plays out in an on-line environment. The relevance of the labour relations context and freedom of expression values will then be discussed.

The plaintiff alleged that the domain names used by the Union, namely "bcaaonstrike" and "bcaabacktowork," and the words used in the meta tags of the site constituted passing off. At one point, for example, the site's meta tags contained the trademark acronyms "CAA," "AAA" and "BCAA." Although many of these references were deleted in October 1999 , the plaintiff maintained that the remaining meta tags were descriptive of the business of the plaintiff.' The use of such meta tags would mean that an individual using a search engine to find key words associated with the BCAA would have the Union site returned to them by the search engine in addition to the BCAA site.

The plaintiffs argued that the domain names and meta tags caused confusion in that the "unsophisticated user of the Internet" 10 might believe that these sites belonged to the BCAA. Because of this, the plaintiff argued, there was a "misrepresentation that the Union website is either a British Columbia Automobile Association Web site or is affiliated or supported by it and the use of the trademark BCAA in the Web site domain name or in the meta tags is an "indicator of source" and a passing off."

described in the judgment.

The following phrase from the meta tags of the Union site was provided as an example: "The British Columbia Automobile Association (BCAA) is a member services organization serving over 700,000 members in British Columbia and the Yukon. BCAA is an affiliate of CAA and AAA." BCAA, supra note 1 at 439 .

i" Ibid. at 440 .

"Ibid. 


\section{A. The Tort of Passing OfF}

The tort of passing off seeks to regulate the nature of competition between rival businesses. In this sense it incorporates an element of consumer protection. ${ }^{12}$ As Professor Vaver has succinctly summarized it, "[p]assing-off aims primarily to prevent the disruption of economic relations by misrepresentation." ${ }^{33}$ Thus a merchant who misrepresents his or her wares or services as those of another may be found liable for passing off. In Canada the three elements of the tort of passing off have been described by the Supreme Court of Canada in Ciba-Geigy Canada Ltd. v. Apotex"14 as "[t]he existence of goodwill, deception to the public due to a misrepresentation and actual or potential damage to the plaintiff." 15 Section 7(b) of the Trade-marks Act, which, along with s. 7(c), codifies the tort of passing off, emphasizes the need for a commercial context:

\section{No person shall ...}

(b) direct public attention to his wares, services or business in such a way as to cause or be likely to cause confusion in Canada, at the time he commenced so to direct attention to them, between his wares, service or business and the wares, services or business of another. ${ }^{16}$

Confusion or misrepresentation between wares, services or businesses thus remains key. This focus of the tort on competition within a commercial context is important in cases such as $B C A A$ where such a context is absent. ${ }^{17}$

Although the tort of passing off has three main elements, Sigurdson J.'s analysis in this case focused on misrepresentation or confusion. As a result, I will direct most of my commentary towards this issue. When dealing with web sites, domain names, and meta tags, there may be two levels of confusion: "initial interest confusion" and the standard confusion common in passing off cases that arises from similarities in packaging, business or product names, lines of business and so on. This makes assessing misrepresentation in the on-line context more challenging.

See discussion of this by Gonthier J. in Ciba-Geigy Canada Ltd. v. Apotex Inc., [1992] 3 S.C.R. 120 at 136-41 [hereinafter Ciba-Geigy]. In Ciba-Geigy, Gonthier J. noted at 134 that "however one looks at the passing off action, its purpose is to protect all persons affected by the product."

13 D. Vaver, Intellectual Property Law (Concord, Ont.: Irwin Law, 1997) at 179.

is Supra note 12.

is Ibid. at 132.

\section{Supra note 4.}

17 Fox argues that s. 7(b) of the statute is actually broader than the common law tort. In his view, the common law tort requires a context of competition between the parties, whereas s. 7(b) simply requires confusion as between wares, services or businesses. However. since the latest edition of Fox on Trade Marks, the common law tort has been moving somewhat in this direction as well. In any event, there is still a requirement that there be confusion between two businesses, their wares or their services. See H.G. Fox, The Canadian Law of Trade Marks and Unfair Competition, 3d ed. (Toronto: Carswell, 1972) at 477-78. 


\section{B. INITIAL INTEREST CONFUSION}

"Initial interest confusion"18 may arise where a domain name is chosen that is close enough to the plaintiff's trademark or domain name that people trying to guess the URL of the plaintiff's site may enter the defendant's domain name and access the defendant's site by mistake. It may also arise where search engines are used to find a site. As a result of the defendant's use of a plaintiff's trademarks or meta tags, a search engine may consistently return the defendant's site, as well as the plaintiff's site, in the search results. Because meta tags are "read" by search engines, they are used to identify web sites that contain key words of interest to the individual conducting an Internet search. Thus a person entering "British Columbia Automobile Association" into a search engine algorithm would likely retrieve the BCAA home page, but would also likely retrieve pages which contained that phrase in their meta tags; in this case, the bcaaonstrike web site. The plaintiff's argued that the retrieval of these two sites from the same search might cause the searcher to believe that they were both BCAA sites, or at the very least, to be confused about the provenance of the second site.

Initial interest confusion has been criticized, particularly with respect to its application to domain names, because it may unreasonably expand trademark rights online. ${ }^{19}$ The problem with initial interest confusion is that it may amount to nothing more than a very "initial" confusion. Mere similarity of domain names alone may not be enough to establish the confusion required by the law of passing off. For example, in one American case ${ }^{20}$ the court noted:

There is a difference between inadvertently landing on a web site and being confused. Thousands of Internet users every day take a stab at what they think is the most likely domain name for a particular web site. Given the limited number of letters in the alphabet, and the tendency toward the use of abbreviations in commerce generally and in domain names in particular, it is inevitable that consumers will often guess wrong. ${ }^{21}$

This notion is most often linked with the on-line context. Although a recent concept, it was developed by American courts in more traditional off-line settings. See Chatam International Inc. v. Bodum Inc., [2001] WL 894085 at 6 (E.D. Pa.), online: WL (DCT) [hereinafter Chatam]. For example, Freedman and Deane have argued that "a rigid and narrow application of the initial interest confusion concept strains fundamental trademark principles. It suggests that a finding of confusion may be based upon a comparison of the conflicting mark and domain name in the abstract, and leads to the view that trademark holders have exclusive property rights in their marks." B.J. Freedman \& R.J.C. Deane, "Trade-marks and the Internet: A Canadian Perspective" (2001) 34 U.B.C. L. Rev. 345 at 374. In the discussion which follows I will refer to and quote from a number of US cases. While these cases are not binding on Canadian courts, they do represent a body of judicial decision-making focused on Internet issues. Absent a similar body of Canadian case law, these decisions are useful analytical tools. Sigurdson J. also referred to and quoted from a number of these cases in reaching his decision.

21 The Nenwork Network v. C.B.S., [2000] WL 362016 (Cal. Dist. Ct. 2000), online: WL (ALLCASES) [hereinafter The Network Network]. 
A recent decision put it more bluntly: "Dissimilarity of goods and services resolves the initial interest confusion question." 22 Without more to substantiate actual or likely confusion, it is difficult to see what would sustain an action. Similarly, with the use of meta tags, one could presume that once the searcher clicked on the different links uncovered by their search, they would be able to distinguish the actual sources of the sites, provided there was nothing more on the web site to deliberately mislead them as to the source. A clear disclaimer, a completely different line of business, or content that could not be expected from the sought after site (such as content highly critical of that site) would all likely dispel any initial interest confusion. ${ }^{23}$ A further difficulty with initial interest confusion is that it is premised upon an inexperienced web surfer. As use of the World Wide Web becomes more commonplace, and users therefore more savvy, initial interest confusion claims arising solely from meta tag content are arguably less and less likely to succeed.

In spite of its problems, initial interest confusion is not irrelevant. It can be one consideration when assessed in conjunction with a range of other factors linked to a more general test for confusion. ${ }^{24}$ In fact, in Brookfield Communications, the Court found that the initial interest confusion was actionable because it could result in consumers who were searching for one site ultimately settling on the products and services offered at the unrelated site that showed up on the same search:

\begin{abstract}
Web surfers looking for Brookfield's "MovieBuff" products who are taken by a search engine to "westcoastvideo.com" will find a database similar enough to "MovieBuff" such that a sizeable number of consumers who were originally looking for Brookfield's product will simply decide to utilize West Coast's offerings instead. Although there is no source confusion in the sense that consumers know they are patronizing West Coast rather than Brookfield, there is nevertheless initial interest confusion in the sense that, by using "moviebuff.com" or "MovieBuff" to divert people looking for "MovieBuff" to its web site, West Coast improperly benefits from the goodwill that Brookfield developed in its mark. ${ }^{25}$
\end{abstract}

The better view of initial interest confusion therefore requires something more than attracting surfers to a web site other than that for which they were searching. It is actionable if it results in a loss of business to the plaintiff's site because customers

Chatam, supra note 18 at 7.

See, e.g., the American case of Northland Insurance Co. v. Blaylock, 115 F. Supp.2d 1108 (Minn. 2000).

In Niton Corporation v. Radiation Monitoring Devices, Inc., 27 F. Supp.2d 102 (Mass. 1998), a case which involved the copying of the plaintiff's meta tags into the meta tags of the defendant's web sites, the Court found a likelihood of confusion sufficient to grant a preliminary injunction. However. the decision did not turn solely on the reproduction of the meta tags. A key consideration was that the two businesses were close competitors, and that the use of the meta tags amounted to unfair competition.

Brookfield Communications v. West Coast Entertainment Corp., 174 F.3d 1036 at 1062 (9th Cir. 1999) [hereinafter Brookfield Communications]. In Convectair NMT Inc. c. Ouellet Canada, [1999] J.Q. No. 1354, online: QL (JQ) appears to be framed as a statutory passing off case under s. 7(b) of the Trade-marks Act. Although not decided on the merits of the s. 7(b) argument, the case involved a claim that the insertion of the plaintiffs trademark (Convectair) forty-four times in the meta tags of a competitor's site would lead to confusion. Anyone using a search engine to search for Convectair would have both the plaintiff's and the defendant's sites returned to them. 
searching for the plaintiff's site using trademarks or trade names associated with the plaintiff are diverted to another site that offers them similar goods or services. The similarity of products and services and the element of competition for the same clientele become key. ${ }^{26}$ It is far less likely that simply using terms in meta tags to attract attention to a web site is actionable as passing off. Certainly in the case of $B C A A$, Sigurdson $\mathrm{J}$. concluded that there was no passing off with respect to Site 3:

[T]here [was] no misrepresentation that the Union site is a site of the plaintiff, or a site that is endorsed by, affiliated with or connected to the plaintiff. I think there is no actionable passing off because there is no confusion or possibility of confusion in the minds of an Internet Web user that the site is associated with or the property of the B.C. Automobile Association. The fact that the current Internet site is not associated with the British Columbia Automobile Association is quickly apparent from looking at the site. ${ }^{27}$

Initial interest confusion alone is therefore unlikely to be a sufficient basis for a passing off claim. A more substantial level of confusion is required.

\section{Confusion Generally}

The assessment of confusion generally in the Internet context may not be significantly different from the assessment of confusion in the bricks-and-mortar world. In the Internet context, courts have considered the following factors in assessing the likelihood of confusion: the registration of a domain name that is strikingly similar or identical to the trademark of another party, ${ }^{28}$ the degree of relationship between the wares or services of the two companies, ${ }^{29}$ and the strength of the plaintiff's mark. The degree to which the companies rely on their on-line presence or marketing may be relevant. ${ }^{30}$ As in other passing off cases, while intent is not necessary, evidence of intent to confuse or deceive

As Sookman notes: "The principle is premised upon the infringer improperly benefiting from the goodwill that the infringed upon owner developed in its mark. The dissimilarity of goods and services resolves the initial interest confusion question." B.B. Sookman, Computer, Internet and Electronic Commerce Law, looseleaf (Toronto: Carswell, 1989) at 5-104. $B C A A$, supra note 1 at $455-56$.

28 See, e.g., British Telecom plc. v. One in a Million Lid., [1998] 4 All E.R. 476; Edgar Online Inc. v. Dan Parisi (1999), D.N.J. Civil No. 99-2288, online: BNA; Planned Parenthood Federation of America v. Bucci, [1997] WL 133313 (S.D.N.Y, 1997), online: WL (ALLCASES), affd 152 F.3d 920 (2d Cir. 1998); Washington Speakers Bureau. Inc. v. Leading Authorities, Inc., 33 F. Supp.2d 488 (E.D. Va. 1999). In $B C A A$ Sigurdson J. noted: "If someone uses a person's trademark as the domain name, such as Marks \& Spencers.com or McDonalds.com, without any other words or letters, that is likely to confuse members of the public who type in the domain name looking for the website of Marks \& Spencers or McDonalds and then come to something else. They will think the website has some connection with the site they were seeking." $B C A A$, supra note 1 at 442. This was one of a number of factors considered in Brookfield Communications, supra note 25, and in The Network Network, supra note 21. The proximity of the two businesses turned out to be a key factor in the Court's finding that there was, in fact, a trademark violation in the use of the domain name complained of. 
can be a persuasive factor, ${ }^{31}$ as can evidence of actual confusion. ${ }^{32}$ In a very early Canadian domain name case, the length of time during which a complained-of domain name was used was considered a relevant factor in assessing possible consumer confusion. ${ }^{33}$ The contents of the web site itself may also be relevant in assessing the level of misrepresentation, such as a strong and visible disclaimer, and language or images that seek to either distinguish the two companies or to cause further confusion as to source.

In reaching his conclusion that there was no passing off with respect to Site 3 , Sigurdson J. noted that the use of a well-known trademark in a domain name, "without any other words or letters," might be likely to confuse the public. However, he distinguished this case as involving a much more descriptive domain name and noted,

[t] ]he domain name that is used by the defendant is not identical to the plaintiff's trade-marks. I think this is significant. The words that were added, "back to work" or "on strike," suggest that the Union site is not the plaintiff's site or a plaintiff-sponsored or affiliated site. ${ }^{34}$

In addition, he found that the use of meta tags had to be considered in context. Sigurdson J. noted that, in general, the use of meta tags was much less likely to confuse the public than the use of another's trademark in a domain name. However, in his decision, Sigurdson J. indicated that it was a relevant consideration that the Union was not, "as it had [been] earlier, using identical meta tags." ${ }^{35}$ It is not clear how the use of identical meta tags would change the passing off analysis in the present case, so long as such use did not result in misrepresentation leading to damage or loss of goodwill because of confusion. It may be that the use of identical meta tags would have to be actionable on some basis other than passing off, such as trademark depreciation under s. 22 of the Trade-marks Act, or possibly even copyright infringement (depending, in both cases, on the content of the meta tags). ${ }^{36}$

\section{Confusion AND THE E-CONSUMER}

Although Sigurdson J. found no passing off with respect to Site 3, his passing off analysis led to a different result for Site 1. This site shared the URL's <www.picketline. com $>$ and <bcaaonstrike.com>. It also replicated what the court found to be significant

This was clearly a factor for the Court in Washingıon Speakers Bureau, Inc. v. Leading Authorities, Inc., 33 F. Supp.2d 488 (E.D. Va. 1999), where the court found the facts to be suggestive of bad faith on the part of the defendant.

12 See, e.g., Harrods Lid. v. Harrodian School, [1996] R.P.C. 697 (G.B.C.A. Civ. Div.).

3 Peinet Inc. v. O'Brien, [1995] P.E.I.J. No. 68 (S.C.T.D.), online: QL (PEIJ).

$3 . \quad B C A A$, supra note 1 at 456.

is $\quad$ bid. at 456.

3. The passing off argument might work if the identical tags were used to attract customers to a business that was a rival to the plaintiffs. In such a case, however, it would be easier to show both misrepresentation and damage to goodwill. In $B C A A$ the absence of a commercial context for the dispute severely undermines any such passing off argument. 
design elements of the BCAA web site. ${ }^{37}$ In assessing whether there was a misrepresentation as to the source of the web site, Sigurdson J. seemed influenced by a perceived intent to mislead. He noted:

I think that certain aspects of the initial Union sites demonstrate an intention to mislead people looking for the BCAA site in order to get the public to read what appeared on its Web site. 1 agree with the plaintiff that the phrase, "Greetings BCAA is on Strike," is inherently confusing because it gives no indication to the visitor that this is not a BCAA site. Additionally, I think that the similarities with the BCAA Web site design that were intentionally adopted and incorporated into the Union Web site suggest such an intention. ${ }^{38}$

He also noted that there were "striking visual similarities" between the two sites. In the view of Sigurdson J., this would be sufficient to confuse a "casual or hurried observer."

In Ciba-Geigy, the Supreme Court of Canada explored the nature of the test person for the tort of passing off. Gonthier J. noted that the consumer to consider in assessing the likelihood of confusion in a passing off claim is the "average customer." In particular, he said

[t] he average customer will not be the same for different products, however, and will not have the same attitude at the time of purchase. Moreover, the attention and care taken by the same person may vary depending on the product he is buying: someone will probably not exercise the same care in selecting goods from a supermarket shelf and in choosing a luxury item. ${ }^{39}$

Quite apart from the wide variations of this standard that may be applied depending on the product, it is difficult to know how to characterize the "average" on-line shopper. ${ }^{40}$

The "casual or hurried observer" test applied by Sigurdson J. is probably derived from the leading English case of Reckitt \& Colman Products v. Borden Inc. ${ }^{41}$ That case, however, dealt with the get-up or packaging of lemon juice squeeze packs. The trial judge

These elements were found by Sigurdson J. to infringe the copyright in the plaintiff's web site. This may explain why the issues of passing off with respect to the most recent site and the earlier sites were divided up in the judgment. The discussion of passing off with respect to the first and second web sites occurs only after the discussion of the issues of copyright infringement. $B C A A$, supra note 1 at 476 .

11 Ciba-Geigy, supra note 12 at 137-38. Note that Sigurdson J. himself cites this passage from CibaGeigy earlier in his reasons (BCAA, supra note 1 at 455 ). However, he does not engage in any assessment of the "average" Internet customer. Further, in his later passing off analysis, he reverts to the "casual or hurried observer" test with no explanation.

For example, in Green v. Schwarz, [1986] O.J. No. 1003, S.C. (H.C.J.), online: QL (OJ), White J. relied on the law of passing off to determine that a spoof of the Roots trademark and logo on sweatshirts was unlawful. In spite of the fact that the defendant's sweatshirts were clearly a spoof, the court found that the defendant was also "cashing in on the goodwill that the plaintiff had obtained for its trademark" (at para. 4). The court noted that "the first impression that an unwary observer would get would be that the defendant's product is in some way related to the plaintiff's product and may indeed have the same commercial provenance" (at para. 3). 
found that the careful and meticulous consumer was not the test person for confusion in that case. Rather, the harried shopper in a hurry was a more accurate measure:

[O]ne is typically dealing with a shopper in a supermarket, in something of a hurry, accustomed to selecting between various brands when there is such a choice, but increasingly having to choose in relation to a wide range of items between the supermarket's "own brand" and one other brand, and no more. $^{42}$

In finding passing off in that case, the House of Lords noted that

[i]t is no answer to say that the diversion of trade which [the trial judge] was satisfied would take place would be of relative shor duration, since the public would ultimately become educated to the fact that there were two brands of lemon juice marketed in such containers and would then be likely to pay more attention to the labels to be sure that they got the brand which they required. His finding was that the diversion would be likely to run into millions of units. ${ }^{43}$

However, the hurried supermarket shopper, picking a product off a shelf, and the web surfer are not easily comparable. A supermarket shopper may be purchasing up to a hundred inexpensive to moderately priced items in the course of one fairly rushed shopping expedition. This is not typical of on-line shopping. It is thus difficult to see how the "web-surfer in a hurry" could be a useful test person in the Internet context. Even assuming a surfer looking for the BCAA site might be confused momentarily by the Union's first web site, that confusion surely would be dissipated as they began to look more closely for the services they sought from the site. In the absence of direct competition in the same e-commerce market for wares or services, it is difficult to see how any kind of actionable confusion could arise. ${ }^{44}$ The difference between the two cases is that in Reckitl, the consumer was deceived into making a choice in purchasing a product, a choice that is normally made very quickly and with little time for reflection, while in $B C A A$, the web surfer was looking for information about a particular product or service.

With the phenomenal rise in home and office Internet access and use, and with the rapid growth of e-commerce, it is increasingly difficult to make generalizations about econsumers. In fact, the average Internet user may be different from the average cybershopper, since not all Internet users engage in electronic commerce. Furthermore, while one might have attributed a certain level of ineptitude or naïveté to early Internet users, or to those who are relatively new to the medium, one's estimation of the capabilities of the average Internet user surely must rise as use of the medium becomes more prevalent. In addition, just as Gonthier J. noted that the nature of the item being purchased may alter the level of care of the average consumer, it may be fair to say that the average on-line shopper is more cautious about the source of the site from which she is purchasing, in large part because of widespread concerns about e-commerce security and the absence of

$42 \quad$ Ibid. at 883 .

4.3 Jbid. at 888 .

4t In fact. Sigurdson J. found only nominal damages for the breach of copyright and passing off. There was no evidence of actual pecuniary loss. 
face-to-face contact. In the absence of empirical data, we are left to speculate about the "average" e-consumer, with such speculation likely being coloured by one's own level of comfort and familiarity with the medium. Courts should be wary of assuming that on-line consumers or consumer habits are the same as those in the off-line context. Unfortunately, to date, courts have little guidance as to how to conceive of the average or ordinary econsumer. ${ }^{45}$

Guidance or not, courts have characterized the "average" web surfer in a number of ways. In one American case, the Court noted:

Our ever-growing dependence on the Web may force us eventually to evolve into increasingly sophisticated users of the medium, but, for now, we can safely conclude that the use of remarkably similar trademarks on different Web sites creates a likelihood of confusion amongst Web users. ${ }^{46}$

Although the Court acknowledged that the sophistication of the average Internet user may be increasing, it was unable to identify a point at which that sophistication might demand a different standard. A more recent court decision provided a different view of web surfers: "Internet surfers are inured to the false starts and excursions awaiting them in this evolving medium. ${ }^{.47}$ However, it is important to note that the proper standard should not be the average web surfer in the abstract, but rather the average web surfer searching for a particular kind of product or service, or perhaps even the likely clientele of a web site. Thus in one American case, the Court determined that "not only is AVC's clientele a small subset of the people likely to use the Web, but the sophistication of those clients is sufficiently high that they can be expected to know the difference between an Internet search service and a literary agency." 48

In a recent article the author argues that the "average consumer" test used in assessing confusion under the Trade-marks $A C t$ is unworkable. Instead, the author argues that judges should use survey evidence tailored to the particular web sites at issue. See K.A. Kitchura, "Would a Domain by Any Other Name Still Smell as Sweet?: The Use of Survey Evidence to Prove Trade-mark Infringement in Cyberspace" (2000) 15 I.P.J. 35. GoTo.com v. Walt Disney Co. 202 F.3d 1199 at 1206 (9th Cir. 2000) [hereinafter GoTo.com]. Chatam, supra note 18 at 6.

The Alia V'ista Corporation v. Digital Equipment Corporation, 44 F. Supp.2d 72 at 78 (D. Mass 1998). In GoTo.com the Court shifted the question somewhat from the sophistication of the web surfer to the nature of the web itself:

Although the use of computers may once have been the exclusive domain of an elite intelligentsia, even modern-day Luddites are now capable of navigating cyberspace. Furthermore, the question in this analysis is not how sophisticated web surfers are but, rather, how high the cost is of choosing one service - that is, one web site - over another on the Web. We agree with our previous conclusion that this cost is negligible: it is simply a single click of a mouse. (GoTo.com, supra note 46 at 1209.)

The point here is an interesting one. In the view of this Court, the sophistication of the web surfer is less important than the fact that once a user is attracted to one site, they may choose to use the services offered by that site instead of the site that they might have initially been searching for. However, if this is to be the basis of a finding of passing off, then the tort really must be confined to commercially competitive contexts since this type of confusion only arises when both sites are offering essentially the same goods or services. The likelihood of confusion, and the resultant depreciation of goodwill, in such circumstances can be assessed using the more traditional criteria. 


\section{E. CONFUSION AND THE INTERNET CONTEXT}

Just as it is important to understand who the test person should be in Internet passing off cases, it is also important to consider what constitutes the "Internet context" into which a tort such as passing off is transplanted. One significant characteristic of this context is the way in which the public arrives at the virtual business. In one American case, for example, the Court emphasized the qualitative differences between on-line shopping and shopping in the "real" world, suggesting that on-line shopping had the inherent potential to give rise to more confusion as to source:

In the Internet context, in particular, entering a web site takes little effort - usually one click from a linked site or a search engine's list; thus. Web surfers are more likely to be confused as to the ownership of a web site than traditional patrons of a brick-and-mortar store would be of a store's ownership. ${ }^{49}$

This may be particularly true in cases where the domain name of one site is identical or very similar to another company's trademark. In addition, it may be difficult to tell the difference between the size and stability of a businesses simply from looking at a web site, whereas it is much easier to draw such conclusions from looking at the physical premises and their location. However, there has yet to be a clear judicial evaluation of the characteristics of the Internet commercial context. Not all web sites are e-commerce sites, and not all e-commerce sites offer the same level of shopping services. While some may provide consumers with the opportunity to fill a shopping cart and to "check-out" their purchases using a credit card, other sites require consumers to take further steps, such as phoning the business and placing the order over the phone, ordering a catalogue to place orders by mail or phone, or actually going to a physical location in order to make the desired transaction. In $B C A A$, the Union site was completely non-commercial: there was no opportunity to purchase products or services from the site, or from a physical location. It is interesting that the Court, continued after this finding, to find passing off with respect to Site 1. The Court seems to be offering compensation for some kind of depreciation of BCAA's goodwill in the guise of the tort of passing off..$^{50}$ It is possible that the problem

Brookfield Communications, supra note 25 at 1057. However, in that case, the other forms of confusion which arose on the facts were very influential in reaching a decision. These factors included a close similarity in the names used by the businesses, and a similarity of products and services.

s" It may be that the Court was unduly influenced by the critical nature of the Union site. It is conceivable that a consumer searching for a particular product may end up at a parody or criticism site, and, after being informed of alleged shortcomings of the company for which they were originally searching, may choose to no longer do business with them. This is likely closer to the $B C A A$ situation, or at least closer to what the BCAA feared in its attempt to stop the Union from operating its web sites. On the one hand, the critical site may be seen to be undermining or damaging the goodwill of the targeted business. On the other hand, if they are not in competition with that business, and are not seeking to profit at the expense of that business from attracting web surfers to their site, it is difficult to see how this fits within the tort of passing-off. Further, it has always been legitimate to offer fair criticism of products or businesses, and this kind of commentary is, so long as it is not defamatory, protected expression. It would be inappropriate to silence such criticism. To structure intellectual property law so that it is impossible to make such criticism reasonably available and easily located on the web through, for example, the use of appropriate meta tags, would not serve the public interest. 
is rooted in a lack of proper assessment of the Internet context or the use of an improper cause of action to frame the wrong.

\section{F. The Relevance of The Strike Context}

In reaching his decision on passing off in this case, Sigurdson J. found the circumstances of the case to be relevant; he noted that "the Union Web site [was] not competing commercially with the plaintiff." ${ }^{\text {si }} \mathrm{He}$ suggested that there was also much less likelihood of confusion in a consumer criticism. Thus it would seem that he saw the context of the site as being one of the relevant factors in an assessment of confusion. A different approach would be to view the lack of commercial competition or, more precisely, the lack of a commercial context, as determinative of the passing off issue. After all, there could be no confusion, to borrow the words of s. 7(b) of the Trade-marks $A c t$, between the "wares, service or business and the wares, services or business of another"s2 if one of the parties does not, in fact, offer any wares, services or business. By reducing the lack of competition to only one of the factors in the assessment of confusion, Sigurdson J. effectively broadened the tort beyond its usual commercial context.

A similar expansion of the tort took place in an earlier case, where a passing off argument was also made in the context of a labour dispute. In Rotisseries St-Hubert, the plaintiffs argued the tort of passing off under s. 7(b) of the Trade-marks Act. Questioning the constitutionality of this section, ${ }^{53}$ the Court chose instead to deal with this matter under private law. Observing that s. 7(b) covered similar territory to the common law tort of passing off, the Court equated the common law action with the right of action in delict under what was then article 1053 of the Civil Code of Lower Canada. ${ }^{54}$ Based on this general delictual provision, the Court found that because the defendants were aware of the intellectual property rights of the plaintiffs in their logos and designs and used them nonetheless, this amounted to a direct and intentional violation of the property rights of the defendant. This result, which was reached without much explicit analysis, emphasizes the proprietary value of the marks without placing them in the context of commercial competition, which is clearly laid out in the Trade-marks $A c t$, and which is a distinct

$B C A A$, supra note 1 at 456.

32 Section 7(b) and (c) of the Trade-marks $A C l$ are commonly held to have codified the common law tort of passing off. (See Vaver, supra note 13 at 176.) The tort is widely viewed to be limited to the context of commercial activity. As one UK source describes passing off: "It is an actionable wrong for the defendant to represent, for trading purposes, that his goods are those or that his business is that of the plaintiff." (See T.A. Blanco White \& R. Jacob, Kerly's Law of Trade Marks and Trade Names, 12th ed., (London: Sweet \& Maxwell, 1986) at 344.)

In the year following this decision, the Federal Court of Appeal upheld the constitutional validity of s. 7(b). See Asbjorn Horgard A/S v. Gibbs/Nortac Industries Lid. (1987), 14 C.P.R. (3d) 314 (F.C.A.). The section is considered constitutional so long as there is a registered or unregistered trademark at issue.

Art. 1053 C.C.L.C. This is also confirmed by the Supreme Court of Canada in Ciba-Geigy, supra note 12 at 133. Art. 1053 reads "Every person capable of discerning right from wrong is responsible for the damage caused by his fault to another, whether by positive act, imprudence, neglect or want of skill." 
feature of the tort of passing off. ${ }^{55}$ This result is different from a finding that there was misrepresentation damaging to the plaintiff's goodwill. Rather, it is a finding of an intentional violation of property rights, which is more akin to the tort of trespass.

The $B C A A$ decision is not as restrictive as Rotisseries $S t-H u b e r t$, and indeed, Sigurdson J. sends mixed messages. Even though he reduced the labour relations context as just another factor in the analysis of confusion, he nonetheless found, at least with respect to Site 3, that there were "legitimate reasons for the Union to use the domain names and the meta tags it presently uses." In particular, he noted that "if a site wishes to operate as a lawful vehicle during a strike or as a consumer criticism site, it must be able to reach people who are attempting to find an employer's or a producer's site." is no confusion, the use of meta tags was "a reasonable way for the Union to bring its message to people wishing to do business with the employer."58 Sigurdson J. accepted the Union's argument that the common law of passing off should be interpreted in a manner consistent with the Charter. ${ }^{59}$ In particular, he noted:

When a Web site is used for expression in a labour relations dispute, as opposed to commercial competition, there is, I think, a reasonable balance that must be struck between the legitimate protection of a party's intellectual property and a citizen's or a Union's right of expression. ${ }^{60}$

While this gives a certain leeway in labour relations matters, it does raise the question of where the balance would be struck, for example, in consumer criticism sites such as "sucks" sites where there is no labour relations dispute. For example, while a union site may simply be trying to gain publicity for its point of view in a labour dispute, a "sucks" site might, through criticism of a business, its products or services, be attempting to divert customers from dealing with the company, and thus might be more likely to be seen as damaging the goodwill of the business. An analysis that does not at the outset screen out cases that do not involve a commercial context leaves much room for shutting down critical commentary.

There are good reasons to carve out space for consumer criticism and even parody sites online. Critical speech, particularly in a highly consumeristic society, can play an invaluable role in informing the public and assisting consumer choice. In ruling on the validity of the use by the defendant of "ballysucks" in a domain name and meta tags, an American court noted:

[T] he average Internet user may want to receive all the information available on Bally. The user may want to access the official Internet site to see how Bally sells itself. Likewise, the user may also want to be apprised of the opinions of others about Bally. This individual will be unable to locate sites containing outside commentary unless those sites include Bally's marks in the machine readable code upon which

See supra note 52.

$B C A A$, supra note 1 at 457.

Ibid.

Ibid.

Canadian Charter of Rights and Freedoms, Part I of the Constitution Act, 1982, being Schedule B to the Canada Act 1982 (U.K.), 1982, c. II [hereinafter Charter]. 
search engines rely. Prohibiting Faber from using Bally's name in the machine readable code would effectively isolate him from all but the most savvy of Internet users. ${ }^{61}$

Further, in a society where large corporations increasingly dominate civic life, expression that parodies those corporations or corporate culture more generally may be as important as parodic political expression, and as worthy of protection. ${ }^{62}$

Rotisseries St-Hubert, which elevated passing off from a tort of unfair competition to a proprietary right, characterizesthe fairly restrictive approach by Canadian courts towards intellectual property rights and freedom of expression. In numerous cases, intellectual property rights have been given precedence over rights of free expression. ${ }^{63}$ This contrasts unfavourably with American case law on the same subject. While Sigurdson J. acknowledged the significance of the labour relations context to the passing off analysis, it was not wholly determinative of the issues. The context appeared to be an important factor in his finding of no passing off with respect to Sites 2 and 3, but it played little, if any, role in his findings with respect to Site 1 . Rather than determining that there was no passing off because there was no commercial context, he appears to have made the labour relations context one of the factors in assessing the element of confusion. The result is less than satisfactory.

\section{G. Passing OfF - Conclusion}

While Sigurdson J. appears to have reached the right decision in finding that there was no passing off with respect to Site 3, his decision with respect to Site 1 raises some questions about adapting the law of passing off to the Internet context, and about the use of the tort of passing off outside a context of commercial relations. The failure to dismiss the action because of the lack of misrepresentation with respect to wares, services or business has the potential of so broadening the tort as to allow the stifling of legitimate forms of critical speech. Sigurdson J.'s view that an action in passing off on the Internet is not foreclosed if the facts and circumstances are appropriate, is in line with emerging UK and US case law. Nevertheless, it remains unclear what standards of confusion will be applied in the Internet context, particularly in circumstances where there is no

Bally Total Fitness Holding Corporation v. Faber, 29 F. Supp.2d 1161 at 1165 (Cal. 1998). There are real differences between US and Canadian approaches to freedom of expression. It is fair to say that the United States takes a much more liberal approach in general, and in intellectual property law in particular. Canadian courts have yet to engage in a full exploration of freedom of expression arguments in the context of the Internet.

The court in GoTo.com, supra note 46 at 1207, noted that "[t]he ever-growing number of tentacled conglomerates may force us to conclude that even one hundred and one products could all be sponsored by a single consortium." Ironically, perhaps, the same growth in power and dominance of the corporate sector that might increase the need for greater protection of freedom to criticize and parody corporate interests is put forward in this case as a reason to extend the scope of protection from confusion. Nevertheless, it does perhaps underline a need to insist firmly upon the limitation of the tort to commercial contexts.

(.) Sec, inter alia. Michelin. supra note 5; Rotisseries St-Hubert, supra note 6; Source Perrier (Societe Anonyme) v. Fira-less Marketing (1983), 70 C.P.R. (2d) 61 (F.C.T.D.) [hereinafter Source Perrier]; Canadian Tire Corporation v. Retail Clerks Union. Local 1518 of U.F.C.W. (1985), 7 C.P.R. (3d) 415 (F.C.T.D.) [hereinafter Canadian Tire]. 
commercial competition between the parties or where one of the parties is not engaged in any form of commerce. At the very least, there is a need to focus on the key elements of the tort and avoid the distracting novelty of meta tags and domain names. In addition, a greater understanding of electronic commerce and the habits of e-consumers is required.

\section{SECTION 22 OF THE TRADE-MARKS ACT}

The plaintiff also argued that the use of its trademarks in the defendant's domain names and meta tags resulted in depreciation of the value of the goodwill in the marks contrary to s. 22(1) of the Trade-marks $A c t$, which reads:

22.(1) No person shall use a trade-mark registered by another person in a manner that is likely to have the effect of depreciating the value of the goodwill attaching thereto.

Earlier versions of the site used the registered trademarks BCAA and CAA in the meta tags, while all three versions used BCAA in two of the URL's which pointed to the site.

\section{A. USE Generally}

The leading case of Clairol International Corp. v. Thomas Supply and Equipment $\mathrm{Co}^{64}$ has established that use in the trademark sense must be a use "for the purpose of distinguishing or so as to distinguish wares or services whether of a particular origin or of a defined standard, from others," Act. Trademark "use" for the purposes of s. 22 of the Trade-marks Act is defined more broadly. While it is still necessary to show that the defendant has "used" the mark(s) in a trademark sense, that use is not limited to the purposes of distinguishing wares and services from others. "Use" in the $A c t$ is defined as "in relation to a trade-mark ... any use that by section 4 is deemed to be a use in association with wares or services." more expansive approach to the "use" requirement gives greater scope to s. 22. Trademark holders are protected both from direct competitors who use their trademarks, or ones that are confusingly similar, and from more general kinds of use that may have the effect of depreciating the value of the goodwill associated with the trademark. That being said, the use must still be in association with wares or services. In this case the only alleged use could be in association with services. Section 4(2) provides that "[a] trade-mark is deemed to be used in association with services if it is used or displayed in the performance or advertising of those services." Thus, even though s. 22 reaches uses other than those made for the purposes of distinguishing wares and services, it is clear that Clairol still requires a commercial context for the use.

\section{B. ACCEPTABLE USE}

The Clairol decision also establishes that some criticism or comparison is legitimate in the commercial context without engaging s. 22: 
There are many common instances of the use of trade marks in the course of trading which I do not think the section could have been intended to prohibit. A trade mark is "used," for example, in this sense in the course of trade when a shopkeeper exhibits a poster on his counter or in his shop with a comparative price list indicating by reference to their trade marks the goods of several traders who may be competitors of one another. It is also used in this sense in the course of trade when a sales clerk makes reference to it in the course of discussing the merits of the owner's goods with a customer, whether in comparison with the goods of other traders or not. Such uses could, depending on what was being said, tend to adversely affect the goodwill attaching to a trade mark but I do not think the statute is intended to forbid legitimate comparisons or criticisms of that kind. ${ }^{67}$

According to Thurlow J. in Clairol, the prohibition in s. 22 seeks to provide a remedy for unfair competition. He notes that a trader

may not put his competitor's trade mark on his goods for ... the purpose of carrying a message to customers who are familiar with the goods identified by the trade mark in order to facilitate their purchase of his own goods and thus to reduce the chance that new customers hearing of the goods identified by the mark would buy them in preference to his or that old customers familiar with the goods identified by the trade mark would have continued buying the goods of the owner of the mark. ${ }^{68}$

Because Clairol presented a set of facts relating to two competitors in the same field of commercial activity, it is possible to argue that there is room to apply s. 22 outside of purely commercial contexts. Clearly the position of BCAA was that the value of goodwill in its marks was being depreciated by the Union's site, absent any competition. However, the interpretation given to s. 22 by Thurlow J. has found general support, ${ }^{69}$ and it would seem that the commercial context is necessary for the application of s. 22.

In this case, the plaintiff BCAA argued that the Union web site was providing services, and that use of the mark was in association with those services. The plaintiff tried to overcome the Clairol hurdle by arguing that the Trade-marks Act "does not distinguish between primary and ancillary services and that the nature of the services rendered in association with a trademark need not be commercial for ss. 22(1) and 4(2) to apply."70 Further, the plaintiff argued that the term "services" required a broad interpretation and that it should mean "something that benefits others and need not be services that have a commercial element." "1

The issues raised by the plaintiffs were addressed directly in the case of Michelin. ${ }^{72}$ The s. 22 issue in Michelin arose in the context of a labour dispute where union pamphlets caricatured the company trademark. In Michelin the Court rejected the s. 22

Clairol, supra note 64 at 196.

Ibid. at 201.

It has been followed in Rotisseries St-Hubert, supra note 6, and in Michelin, supra note 5, where it was carefully assessed; it was also cited with approval by the Federal Court of Appeal in Syntex v. Apotex Inc., [1984] 2 F.C. 1012 (F.C.A.) at 1020-21. See also S. Burshtein, "Trade-Mark Use in Canada: The Who, What, Where, When, Why and How (Part II)" (1997) 12 I.P.J. 75 at 113. $B C A A$, supra note 1 at 461 .

Ibid.

Supra note 5. The plaintiff argued that this case was wrongly decided. 
argument on the basis that there was no "use" of the marks in association with wares or services. More specifically, the court noted that " $[\mathrm{h}]$ anding out leaflets and pamphlets to recruit members into a trade union does not qualify under that test as commercial activity." ${ }^{\prime 3}$ Further, handing out leaflets was found not to constitute "advertising" within the meaning of s. 4(2) of the Trade-marks $A c t$, as "advertising carries a commercial connotation that is not borne out by the facts of this case." ${ }^{74}$

The plaintiff's argument that Clairol should be restricted to commercial contexts, and that Michelin was wrong in applying Clairol to a labour context, was rejected by Sigurdson J. In his view, any "services" provided through the Union's web site were clearly non-commercial, ${ }^{75}$ and to broaden the reasoning of Clairol to non-commercial contexts "would place an unwarranted restriction on free speech." 76

Although the issue of services alone would have been sufficient to dispose of the matter, Sigurdson J. further found that in this case there was also no depreciation of goodwill. Although acknowledging that the reputation and goodwill of a company may be tarnished during the course of a labour dispute, he located any such depreciation of goodwill not in the use of the trademarks of the company, but in the success of any Union arguments to persuade the public of the merits of their position. In his words:

If a trade-mark appears on a picket sign or on the Web site, does it depreciate the goodwill associated with that trade-mark as that term is used in this section? I do not think so. Any depreciation of goodwill was not brought about by the manner of the use of the trade-mark. Rather it might be said to occur if the Union is successful in its arguments in support of its members. ${ }^{77}$

In the view of Sigurdson J., a contrary finding would unduly restrict free speech. He further found that there was, in any event, no depreciation of the goodwill, and noted that

[t]he Union is entitled to express its position and speak freely provided it does not violate $s$. 22 of the Trade-Marks Act. I think that to accept the plaintiff's argument, that the reference to an employer's trademark to identify a Union site depreciates goodwill associated with that trade-mark, would be a result that goes far beyond what Parliament intended by s. $22 .^{78}$

Sigurdson J.'s decision on the 5.22 issue is not a surprising one, as it conforms to earlier lower court decisions. It confirms a trend that, while yet to be directly examined by an appellate court, reflects sound and increasingly widely accepted reasoning as to the proper interpretation of s. $22 .{ }^{79}$ It also reflects a willingness to balance trademark rights with freedom of expression. By limiting the application of s. 22 to commercial contexts, it

$73 \quad$ Ibid. at 367.

$74 \quad$ lbid. at 368 .

75 The alleged "services" included the provision of hyperlinks, an electronic bulletin board service, the provision of general information about the labour relations dispute, and generally providing information to the public through the web site. $B C A A$, supra note 1 at 463-64.

$76 \quad$ Ibid. at 463.

$7 \quad$ Ibid. at $466-67$.

$78 \quad$ lbid. at 467.

$79 \quad$ See supra note 69. 
leaves room for some critical commentary from unions, consumers or other groups or individuals not in direct competition with the trademark holder. What remains unexplored are the precise boundaries between use of the mark in a trademark sense and use in a critical or non-commercial context. In $B C A A$, Sigurdson J. suggested that his decision might have been different if the Union had been "charging a fee or seeking a profit." It is not entirely clear whether a cost-recovery fee would be sufficient to render the services commercial, or if a consumer group, for example, which sought to raise funds to support its activities as a watchdog by charging a fee for information, would be considered to have entered the commercial realm. ${ }^{81}$

It is also uncertain whether an attempt to parody or spoof a particular product or company would survive judicial scrutiny under trademark law. In Source Perrier a political spoof using bottled water packaging similar to that of Perrier was found to violate s. 22 of the Trade-marks Act. ${ }^{82}$ The Court in that case found that depreciation of goodwill flowed from the attempt "to cash in on the well-established reputation of Perrier. ${ }^{183}$ However, in Source Perrier the defendants were selling a product. This moved the use into a commercial context that might not exist for a simple parody web site. Further, the spoof was not of Perrier's product, but rather of Pierre Elliot Trudeau. There may be some significance to this; a satire or parody of a product/song/trademark, and so on, that is aimed at the parodied product/song/trademark may be treated differently in law than one that merely uses someone's intellectual property in order to parody or satirize something or someone unrelated. With respect to the freedom of expression argument in this case, the court noted that "the most liberal interpretation of 'freedom of expression' does not embrace the freedom to depreciate the goodwill of registered trademarks, nor does it afford a licence to impair the business integrity of the owner of the marks merely to accommodate the creation of a spoof." ${ }^{\prime 84}$

A final clarifying point from the $B C A A$ decision is that Sigurdson J. regarded the type of web activities engaged in by the Union in this case to be akin to leafleting or picketing. He equated these by asking "[i]f a trade-mark appears on a picket sign or on the website, does it depreciate the goodwill associated with that trade-mark as that term is used in this section? I do not think so." ${ }^{85}$ It is an interesting equation, as pickets and leaflets tend to be distributed within fairly narrow geographical boundaries, such as outside the picketed premises or on public streets near the employer's operations. A web site, by contrast, can

$B C A A$, supra note 1 at 464.

In Michelin the Court dealt with the argument that the union was either a commercial enterprise or at least had "commercial dimensions to its activities," supra note 5 at 367 . Because the union stood to gain "over one million dollars per year in union dues if it had successfully organized the 3000 workers at Michelin's [sic] Canada's Nova Scotia Plants," (at 366-67), the plaintiff sought to have it characterized as advertising its services in a commercial context. The court rejected this characterization, finding that dues could not be equated with profits.

Supra note 63.

Ibid. at 65 .

Ibid. at 67. Note that the judge indicates that the targets of the spoof were politicos; Perrier was effectively an innocent bystander whose product was used as a vehicle for the spoof.

$B C A A$, supra note 1 at $466-67$. 
attract visitors from around the world. Geographical spread may have been a relevant consideration for Teitelbaum J. in Michelin when he wrote:

The leaflets and pamphlets were not distributed to the wider community but directed solely to Michelin Canada's 3000 employees at the Nova Scotia plants. In effect, the CAW's unionisation literature might diminish CGEM Michelin's reputation as an employer, but I am not satisfied that the Plaintiff has proven that the leaflets and posters will deleteriously affect Michelin's reputation as a manufacturer, its specific role in the marketplace. Now undoubtedly some of Michelin's 3000 employees at the plants in Nova Scotia purchase Michelin tires, but they compose a minuscule portion of the market. ${ }^{86}$

It is difficult to tell from this whether the geographical spread of the material is a relevant factor in assessing depreciation. Following Clairol it would seem that the lack of use of a mark in the trademark sense means that s. 22 of the Trade-Marks Act will not apply. It remains to be seen whether the simple analogy struck between web sites, pickets, and leaflets in $B C A A$ will be explored in further cases.

\section{COPYRIGHT INFRINGEMENT}

The BCAA claimed that the two earlier versions of the Union's web site violated its copyright in their own web site because the Union's sites substantially reproduced the appearance of its site. The Union countered by arguing that because the BCAA's site was based on fairly commonplace materials, an application of the abstraction-filtrationcomparison test ${ }^{87}$ would be required to filter out those parts that were unprotectable expression. Essentially, they argued that once the standard elements and those dictated by the technology and basic principles of web design were filtered out, there would be little left to constitute the copyright protected work of the plaintiff. In such circumstances, it was argued, only literal copying would be infringement as even minor variations would render the second work non-infringing. ${ }^{88}$

In finding for the BCAA Sigurdson J. avoided making any ruling with respect to the applicability of the American abstraction-filtration-comparison test. Incorporating the principles underlying the test, he enunciated a more generalized view of the proper approach to take:

*. Michelin, supra note 5 at 371-72.

"77 This test was developed in American case law, see: Computer Associates International v. Altai, Inc., 982 F.2d 693 (2d Cir. 1992). The test has never been formally adopted in Canada, although it was mentioned in Delrina Corp. v. Triolet Systems (1993), 47 C.P.R. (3d) I (Ont. Gen. Div.). Kenrick \& Co. v. Lawrence \& Co., (1890), 25 Q.B.D. 99 (T.D.), Boutin v. Bilodeau (1992), 46 C.P.R. (3d) 395 (Qc. C.A.), rev'd (1994), 54 C.P.R. (3d) 160 (S.C.C.). The Court of Appeal in Boutin found no infringement in two similar scratch and win lottery tickets on the basis that, in spite of "important and substantial" similarities between the two tickets, many of these similarities flowed from being in the genre of scratch and win tickets. The finding that "the one is not a simple copy of the other" was enough for the Court to find no infringement. The Supreme Court of Canada reversed, ruling that it was erroneous to find that the law required one to be a simple copy of the other. 
It is the overall arrangement of the components that is important to determining whether the plaintiff has copyright in an original work. Substantial copying cannot be defined precisely. The question is whether on a qualitative, not simply a quantitative basis, there has been substantial copying. It is said to be a matter of fact and degree. The court must exclude portions of work that are not subject to copyright, such as ideas or information. I recognize that the characteristics of Web sites to some degree must be dictated by function. Additionally, the constraints imposed by technology or the nature of the product may not indicate copying. However, it should be recognized that the overall arrangement of commonplace elements such as colours, shapes and designs can obviously result in an original artistic work for which the author is entitled to copyright protection. ${ }^{89}$

Sigurdson J. found that the plaintiff had an artistic copyright in its web site, and that the copyright included "the look, layout and how the Web page appears to operate." By using similar colours and features, including the trademarks BCAA and CAA, the term "on-ramp," the use of the same number and location of frames, and similar navigation features, the defendant had substantially copied the original work of the plaintiff. Although the Union argued that many of these features were standard design features, and were thus not protected under copyright, Sigurdson J.'s conclusion was that

[t]here are extensive visual similarities between the 1997 BCAA site and the first Union Web sitc, and the inference that $I$ conclude must be drawn on the evidence is that the author of the Union Web site has copied the plaintiff's original Web site in the creation of the first Union Web site. The evidence I think shows that it was substantially copied. ${ }^{91}$

He went on to note, countering the defendant's arguments regarding the commonplace features of the plaintiff's site, that

[a]lthough many of the elements of the design of a Web page are commonplace and standard, the same might be said of most artistic works. It is the organization of those elements in a unique and original way that allows a party to have copyright protection.... The 1997 Web site was an original artistic work. It had certain colours, frames, margins, logos, apparent navigation tools and a particular arrangement of those items. ${ }^{92}$

This finding of copyright infringement is not entirely surprising, given that there was evidence that it was the Union's intent to come up with a web site that would be similar in appearance or even identical to that of the BCAA. ${ }^{93}$

\section{A. FAIR DEALING}

The Union argued in its defence that any copying of the general appearance of the BCAA site was fair dealing. In particular, they argued that in emulating portions of the 
BCAA site, "it sought to create the virtual equivalent of a picket line."94 They argued that their site provided both criticism and a parody of the BCAA site. The relevant portion of the fair dealing defence is found in s. 29.1 of the Copyright Act:

29.1 Fair dealing for the purpose of criticism or review does not infringe copyright if the following are mentioned:

(a) the source; and

(b) if given in the source, the name of the

i. author, in the case of a work,

ii. performer, in the case of a performer's performance,

iii. maker, in the case of a sound recording, or

iv. broadcaster, in the case of a communication signal. ${ }^{95}$

The fair dealing defence was amended in $1993^{96}$ to require the provision of source and name of author of the work that was criticized or reviewed. Sigurdson J. found that since the Union site did not appropriately acknowledge the source from which it was partially copied, it could not constitute a fair dealing under s. 29.1.

Sigurdson J.'s decision to reject the fair dealing defence stopped at the point of finding that the Union had not mentioned the source of the site, and thus it did not qualify for the s. 29.1 defence. It is difficult to determine, therefore, whether he was also of the view that the site a) qualified as a criticism of the BCAA site; or b) constituted a parody, assuming parody falls within the scope of the fair dealing defence. In fact, neither of these conclusions are a given. The Union site was designed primarily to criticize the employer, and a narrow reading of s. 29.1 would mean that this was insufficient to invoke s. 29.1, as the criticism must be of the work itself and not some other target. Further, it is far from clear that parody is accepted as fair dealing in Canada, and at least one other court in a similar context has ruled that it is not. ${ }^{97}$

\section{lbid. at 475.}

R.S.C. 1985 , c. C. 42 .

An Act to amend the Copyright Act, S.C. 1993, c. 44.

In Michelin, supra note 5, while considering a similar issue, the Court went further and found that in Canada parody was not a part of the fair dealing defence. It did not fall within the notion of "criticism" allowed in s. 29.1. Teitelbaum J. wrote: "I do accept that parody in a generic sense can be a form of criticism; however, it is not 'criticism' for the purposes of the Copyright Act as an exception under the fair dealing heading." (at 381.) This exclusion of parody from the realm of criticism is potentially very limiting of freedom of expression in relation to copyright works. In any event, in rejecting the American approach to parody and fair use, Teitelbaum J. justifies a difference in the Canadian approach, citing the requirements to provide a mention of the source and author of the work under Canadian law. However, he later deals with this as a separate reason why the fair dealing defence could not succeed. The better view is that a parody is acceptable as criticism as long as the parody is critical of the source. Not only is this consistent with American law on the subject, it is also reconcilable with the wording of s. 29.1 of the Copyright Act. In a recent article Fewer notes: "Under Canada's copyright defence jurisprudence, it is far from clear that the law countenances the degree of appropriation required for an effective parody": D. Fewer. "Constitutionalizing Copyright: Freedom of Expression and the Limits of Copyright in Canada" (1997), 55 U.T. Fac. L. Rev. 175. 
Leaving aside those issues for the moment, the fact that Sigurdson J. decided the issue on a narrow reading of $\mathbf{s}$. 29.1 is problematic. His interpretation of the section is disappointing, particularly in light of his willingness to consider the Charter and Charter values in his discussion of both passing off and trademark law. The ironic interplay between trademark and copyright law in these circumstances has been noted by Professor Vaver who writes that "[t]he strange thing is that trade-mark law may not have been violated by these acts; so copyright, as applied, has produced a result apparently at odds with trade-mark policy." ${ }^{98}$ Thus while trademark law permits non-commercial uses of trademarks, copyright law places limits on all uses of trademarks that also fall within the scope of copyright law, regardless of the nature of the use. Sigurdson J.'s reading of $s$. 29.1 was extremely narrow and demonstrated none of his earlier openness to freedom of expression values.

Section 29.1 and the narrowness of judicial interpretations of the fair dealing exceptions leave only the narrowest scope for critical uses of works. While the requirement of acknowledgement of source is appropriate and well-suited to, for example, a newspaper criticism or review of a book or article from which excerpts are taken, it is more difficult to see how it fits with parody, or with the kind of critical use that might arise in the context of a labour dispute. Indeed, Professor Vaver has argued that this requirement poses such a difficulty for parody that it would be better to treat parody from the outset as non-infringing. ${ }^{99}$ This approach would work where the parody is considered to be sufficiently original to constitute a work in its own right. Unfortunately, parody by its nature must borrow sufficiently from the target work to be successful. This complicates the argument, and makes it less likely to fare well with the courts. ${ }^{100}$

Failing a finding that parody does not infringe copyright, a defendant must claim the defence of fair dealing in s. 29.1. Unfortunately, s. 29.1 requires a "mention" of source in order to meet the requirements of criticism or review. If a "mention" entails an explicit statement of acknowledgement, then it would be difficult for a parody to qualify. If a mention, however, can flow from the fact that a parody is implicitly critical of the source, it might be possible for this type of work to qualify for the defence. However, not only is the status of parody in Canadian law uncertain, but also the argument that "mention" deserves a more flexible interpretation has already been considered and rejected by at least one court.

This argument was made by the defendants in the Michelin case, who claimed that "'mention' means a casual allusion that is met by parody's implicit acknowledgement of the original by the mere fact of its necessary similarity to the original work." 101 Teitelbaum J. rejected this argument, finding that it would not work where the parody was of poor quality, poorly executed, of an obscure source, or received by a particularly dullwitted audience. Further, Teitelbaum J. noted:

98 Vaver, supra note 13 at 84.

w) Ibid. at 103

100 The American case Rogers v. Koons, 960 F.2d 301 (2d Cir. 1992) illustrates how little scope may be provided to artists and others who draw heavily on other works for critical or parodic expression. 
According to the Defendants. the "Bibendum" depicted on the union leaflets and posters has to be similar enough to the Michelin original to implicitly "mention" the source but distinctive enough that it substantially reproduces the Michelin original but still constitutes a new work of criticism. The two facets of this argument are paradoxical and cannot be reconciled. ${ }^{102}$

What the Court is implying is that if a work is close enough to the original to evoke the author and source of the original, then the copying of the original would be substantial enough to constitute infringement. Yet these aspects may be far less difficult to reconcile. The depiction in this case of the Bibendum, or "Michelin Man," with a menacing appearance stomping on workers, is both evocative of and critical of the company which used the Bibendum as part of its logo. ${ }^{103}$ Perhaps the real problem is that the Bibendum is a corporate symbol, and criticism or parody of that symbol is effectively a criticism/parody of the corporation. Even in the United States, where parody may qualify for the fair use defence, the parody must be of the work itself and not of something else. ${ }^{104}$ It is unclear whether a critique of the author or owner of the work would be a legitimate parody.

The problem with corporate logos or symbols is that they differ from the more author/artist-created works that have been the subject of case law on copyright infringement and fair dealing. Corporate logos or designs may be discrete and simple, but through marketing they may gain a tremendous power to evoke the corporation behind them, its products, or its practices. To require that a legitimate criticism or parody be of the work alone, and not the corporation or products that it evokes, prohibits critics from disseminating or promoting their perspectives through the powerful vehicle of critically altering the evocative symbol. ${ }^{105}$ Yet Teitelbaum J. made no distinction between more traditional literary/artistic works and corporate logos. He noted that the use of the Bibendum design by the union in that case was only marginally relevant to the union's message:

The Defendants had no need to adopt a form of expression, the use of copyrighted material, that deprived the Plaintiff of its property and actually subverted the third value of promoting the diversity of ideas. In other words, if copyright is not respected and protected, the creative energies of authors and artists in furthering the diversity of ideas will not be adequately compensated or recognized. ${ }^{106}$

These are fairly lofty sentiments considering that what is at issue is a corporate logo. The result is to place limits upon a potentially important form of critical speech.

lbid. at 383.

Teitelbaum J. also went on to find that this depiction did not meet the requirements of fair dealing because it was not a "fair" criticism of the source. Teitelbaum J. found that to be fair, the treatment of the copyright must be in good faith, and he cited the following dictionary definition of fair as being "free from discrimination, dishonesty, etc. just; impartial" (ibid. at 384).

See Campbell v. Acuff-Rose Music Inc. 510 U.S. 569 at 580-81 (S.C. 1994) [hereinafter Acuff-Rose]. As David Vaver writes, "The uncertainties surrounding substantial infringement work very much to the advantage of powerful right-holders, and quite often to the disadvantage of the general community and the values of free expression," supra note 13 at 84 .

Michelin, supra note 5 at 396. 
Teitelbaum J. would carve out the following space for parody:

Parody would be protected against charges of infringement by its dissimilarity to the original work as long as it did not produce a substantial portion of the original....As well, creative works depicting some critical variation of the "Bibendum" could be protected under the umbrella of "criticism" within the context of a newspaper or journal article describing CGEM Michelin and its subsidiary Michelin Canada. ${ }^{107}$

Teitelbaum J.'s remarks imply that commercial symbols or logos, which receive the protection of copyright law, are off limits to parody because of the brevity with which they convey their original message. It is easier to parody a novel or short story, for example, because in creating the parody, one can both evoke the original and create a work that is sufficiently distinctive to be considered original (although presumably the source and name of the author of the original work would nonetheless have to be credited). It is much more difficult to parody a logo or symbol according to Teitelbaum J.'s reasoning. Ironically, therefore, the rules of copyright give stronger protection to corporate symbols than to literary or other creative works. As Professor Vaver notes:

The restrictive treatment of parody by trade-mark and copyright law - penalizing humorous comments on products or business activity - is an example of business interests being overly protected to the disadvantage of an effectively operating public domain. Intellectual property law as written does not mandate these results. They come from knee-jerk tendencies to interpret the law to prefer business investment over critical comment, and not to ignore some grievances as de minimis. ${ }^{108}$

In Vaver's view, the narrowness of the law relating to parody flows not so much from the legislation as it does from courts, which have either failed to or are unwilling to strike the appropriate balance between holders and users of the copyright.

\section{B. Freedom of EXPRession and the fair Dealing Defence}

In Michelin, Teitelbaum J. considered and rejected s. 2(b) freedom of expression arguments:

I agree with the Plaintiff's submission that the Defendants are not permitted to appropriate the Plaintiff's private property - the "Bibendum" copyright - as a vehicle for conveying their anti-Michelin message. Thus, the Defendants' expression is a prohibited form or is subject to ... a "special limitation" and is not protected under the umbrella of Section 2(b). ${ }^{109}$

He cited as support for this proposition the pre-Charter Supreme Court of Canada decision Harrison v. Carswell, ${ }^{110}$ which recognized as a fundamental freedom "the right of the individual to the enjoyment of property and the right not to be deprived thereof,

\footnotetext{
1117) Ibid. at 385.

I0x Vaver, supra note 13 at 12.

(1r) Michelin, supra note 5 at 391 .

III) [1976] 2 S.C.R. 200 [hereinafter Harrison].
} 
or of any interest therein, save by due process of law." equated this case, dealing with an issue of trespass to land, with the situation in relation to copyrights. He noted that "[t]he Plaintiff's copyright is private property," 112 and further held

I hold that a person using the private property of another like a copyright, must demonstrate that his or her use of the property is compatible with the function of the property before the Court can deem the use a protected form of expression under the Charter. In the present case, subjecting the Plaintiff's "Bibendum" to ridicule as the object of parody is not compatible with the function of the copyright. A "Bibendum" about to stomp hapless workers into submission does not present the original author's intent of a favourable corporate image or provide an incentive for compensating artists for the integrity of their vision. ${ }^{113}$

Once again the corporate logo is conflated with the works of more traditional creative artists. ${ }^{114}$ Yet the "favourable corporate image" is in reality nothing more than the goodwill associated with the mark, and it is something that trademark law chooses not to protect in this type of context. This kind of copyright protection extended to corporate logos is thus overly broad and insufficiently nuanced..$^{115}$

The privileging of private rights over freedom of expression is particularly troubling in relation to intellectual property. Intellectual property rights, and copyrights in particular, have never been absolute property rights. Copyrights are created entirely by statute ${ }^{116}$ and are considered to be qualified monopolies, which balance the right-holder's interests with those of the society more generally. In copyright law, the qualified nature of the rights are evidenced by, inter alia, the limited term of protection, the exceptions to infringement, the notion of the public domain, the idea/expression dichotomy, and the requirement of substantial taking for infringement to be found. To equate copyrights with private property rights short circuits the much more contextual analysis required by copyright law. Even in the context of private property, the late Laskin C.J.C., dissenting

Ibid. at 219.

Michelin, supra note 5 at 394.

Ibid. at 399.

For another labour relations case involving the alteration of a corporate logo in which copyright infringement was found, see: Canadian Tire, supra note 63.

It is interesting that the test for fair use developed in the United States and applied by the US Supreme Court in Acuff-Rose, supra note 104, incorporates four elements for consideration. The fourth, and by no means the least important, assesses the impact of the defendant's use of the work on the potential market for, or value of, the work. This may provide scope in the case of parodies for an evaluation of the extent to which the works are actually competing for the same market, or whether the defendant's work seeks to exploit a different market or no market at all. In Acuff-Rose the US Supreme Court also noted that in assessing parodies in relation to this element of the fair use test, it was not problematic if a parody diminished the market for the original work (as a successful criticism may well have that effect) as long as it did not usurp the market for the work (ibid. at 59192). For a comparison of American and Canadian approaches to parody under the fair use/fair dealing defences, see: C. Ng, "When Imitation is not the Sincerest Form of Flattery: Fair Dealing and Fair Use for the Purpose of Criticism in Canada and the United States" (1998) 12 I.P.J. 183.

Compo Co. v. Blue Crest Music Inc., [1980] I S.C.R. 357 at 372-73. 
in Harrison v. Carswell, made a compelling argument for a more textured understanding of private property. He wrote:

The considerations which underlie the protection of private residences cannot apply to the same degree to a shopping centre in respect of its parking areas, roads and sidewalks. Those amenities are closer in character to public roads and sidewalks than to a private dwelling. All that can be urged from a theoretical point of view to assimilate them to private dwellings is to urge that if property is privately owned, no matter the use to which it is put, trespass is as appropriate in the one case as in the other and it does not matter that possession, the invasion of which is basic to trespass, is recognizable in the one case but not in the other. There is here, on this assimilation, a legal injury albeit no actual injury. This is a use of theory which does not square with economic or social fact under the circumstances of the present case. $^{117}$

It is disappointing to see courts making a blunt analogy between intellectual property and private property, thus shutting the door on Charter analysis.

An appropriately textured analysis would consider a range of factors as bearing on the analysis of infringement, fair-dealing, and on the relationship of the interpretation of the statute to the Charter or Charter values. In Michelin and in BCAA the Courts were dealing with labour disputes and with the issues of expression that arise in such disputes. In Kmart Canada Ltd. v. U.F.C.W., Local 1518 the Supreme Court of Canada discussed the relationship of leafleting in labour disputes to s. 2(b) of the Charter. The Court noted that "workers, particularly those who are vulnerable, must be able to speak freely on matters that relate to working conditions. For employees, freedom of expression becomes not only an important but an essential component of labour relations." 118 It can certainly be argued that the decisions in Rotisseries St. Hubert, Michelin, and BCAA do not eliminate the right to free expression of workers in a labour dispute. Rather, the argument would go, they are merely restrained from using the copyright protected symbols, logos, or web site designs of the employer. Yet, as already discussed, to deny employees in labour disputes the right to parody the most powerful and evocative symbols which the public associates with the employer is to place a substantial limitation on their right to disseminate information about their labour dispute.

The situation is somewhat different in $B C A A$ where the appropriation was of the "look and feel" of the employer's web site and not of a particular logo or symbol. Further, the parodic elements are less clear. Instead, the Union sought to create a "virtual picket line." In essence, they wanted to evoke the on-line "storefront" of the BCAA in order to establish an informational picket outside of it. In Kmart Canada Cory J., for a unanimous Supreme Court of Canada, cited with approval the following comments of the British Columbia Labour Relations Board:

The ability to leaflet and handbill, to give speeches and directly canvass consumers, is a longstanding and traditional form of freedom of expression. It is inexpensive and may be the only form of expression to which many individuals or groups have access in order to influence members of the public. In the facts 
of this case, many of the activities took place at stores located in shopping malls which have been characterized as the equivalent forum to the public markets or main streets of the past. ${ }^{119}$

Certainly the Internet has been heralded as a crucially important vehicle for promoting the values of free expression because of its greater accessibility to a whole spectrum of society than traditional forms of media both in terms of cost and editorial control. ${ }^{120}$ It has also been recognized as a public space of sorts. ${ }^{121}$ In terms of electronic commerce, it can play the role of a public marketplace.

It is certainly arguable that what the Union did was legitimate in this very unique context and was analogous to leafleting outside a public space. The question is whether it is legitimate to copy elements of the targeted employer's "storefront" to do so. Whether this is fair dealing certainly seems to fall outside of the typically narrow readings of that already narrow defence. However, it is an interesting argument and one that might have even more Charter support than an argument for the ability to parody a corporate logo. It is also an argument that will require courts to consider the particular context of the Internet. $^{122}$

\section{CONCLusion}

After the decision was reached in $B C A A$, the defendant Union placed on its web site a list of "Cyber Picketlines Do's and Don'ts." 23 This list represented the lessons learned from the legal dispute over the web site. It is clear that the Union was reasonably satisfied with the results of the case and was willing to offer guidance to others seeking to establish cyber-picket lines for labour disputes. The Union encourages the use of the employer's meta tags, and it also encourages the registration of "all the domain names you can, for all of your bargaining units before employer's [sic] get on to the idea and reserve them before you." With respect to the copyright issues, the Union cautions: "Don't go too far in copying website design, logos or in giving the employer the opportunity to involve other laws not designed or updated for labour relations." 124

Perhaps it is not so much that copyright law is poorly designed for the labour relations context. The law itself is open to a variety of interpretations, and scholars have been calling on the courts for some time now to do more than apply a narrow approach to issues of infringement and fair dealing, particularly in relation to criticism and

Ii) Ibid. at $1103-1104$.

121) See, e.g., Zeran v. America Online, 958 F.Supp. 1124 (Ed. Va. 1997).

121 It is a common cliche that the Internet is an information "highway."

122 Vaver queries. "will the Internet be recognized as a new form of communication that may require all present intellectual property constraints to be reshaped in the light of the imperatives of free expression?" (Vaver, supra note 13 at 19.)

123 D. McPherson, "Employees back at work Strike over after one year on picket lines," online: OPEIU

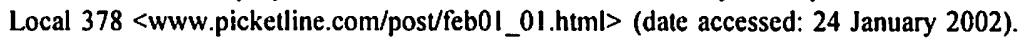

124 Ibid. 
parody. ${ }^{125} B C A A$ takes its place as the most recent in a growing line of decisions that fail to explore the underlying policy issues in copyright, and as a result, privilege private property over all other values and interests at issue.

It is ironic that plaintiffs in cases such as this one have far greater difficulty protecting their marks or logos under the law of trademarks or passing off than they do under copyright law. Copyright law has emerged as the corporate weapon of choice in labour disputes and against other critics. Laws specifically designed and tailored for application in commercial contexts are not easily transplanted, and rightly so, to contexts where criticism and protest, rather than competition, are at issue. Section 22 of the Trade-marks $A c t$, for example, has been of little assistance to plaintiffs outside of commercial contexts, and it was of no assistance to the BCAA in this case. In these circumstances, it is significant that in $B C A A$ the tort of passing off was found to apply to a Union's cyberpicket line. It is unclear yet whether this is simply an unfortunate decision, clouded by the mystique of meta tags and domain names, and perhaps overshadowed by copyright law, ${ }^{126}$ or whether it signals a new trend in judicial approaches to passing off.

From an Internet law point of view, $B C A A$ gets mixed reviews. On the one hand, the intellectual property issues raised were treated in a manner very similar to how they are treated in off-line contexts, thus presumably bolstering comfort levels at the greater predictability of the application of law online. On the other hand, while it is appropriate to apply existing law to the Internet context, it is dangerous to do so without a full and complete exploration of that context. In $B C A A$, while lip service was paid to the Internet context, there was no attempt to evaluate the e-consumer or even the more specific electronic commerce context. In fairness to Sigurdson J., there was not much to turn to on those topics, either in case law or scholarly commentary. BCAA illustrates in a number of ways the need for greater research, scholarship, and critical commentary on the application of existing laws to the Internet. 115; and J. Zegers, "Parody and Fair Use in Canada After Campbell v. Acuff-Rose" (1995) 11 C.I.P.R. 205.

126. Sigurdson J.'s analysis of passing off for Site 3 came first in his decision. His analysis of passing off with respect to Site 1 came last - only after he had discussed copyright law and found that Site 1 infringed copyright. In this respect, the copyright infringement and passing off seem to be very closely linked in his reasoning. 